\title{
Sharia Screening Methodology: Does Its Non-Unification Affect Its Implementation?
}

\author{
Nawal Hussein Abbas Elhussein ${ }^{1} \&$ Salah AbdAlla Abd Elmahmoud ${ }^{2}$ \\ ${ }^{1}$ School of Management Studies, University of Khartoum, Khartoum, Sudan \\ ${ }^{2}$ Dar Alkatiboon for Accounting, Auditing \& Financial Consultancy, Khartoum, Sudan \\ Correspondence: Nawal Hussein Abbas Elhussein, North York, Ontario, 3MA 1E2, Canada. Tel: 1-289-724-2722. \\ E-mail: nawalelhussein80@gmail.com
}

Received: March 6, 2021

Accepted: April 9, 2021

Online Published: May 15, 2021

doi:10.5539/ijef.v13n6p59

URL: https://doi.org/10.5539/ijef.v13n6p59

\begin{abstract}
This paper attempts to empirically assess the possibility of applying Sharia screening criteria in the Sudanese corporate sector and investigate the possibility of extending the external Auditors' role to include reporting on Sharia compliance of corporate activities. The hypotheses of the study revolved around identifying whether the Sudanese stakeholders accept the application of the Screening Criteria as part of the compliance methodologies to cater for companies with mixed activities, whether the Sudanese stakeholders consider available Screening Criteria as effective and robust in the control of Sharia impermissible economic activities, and whether expanding the responsibilities of external auditors to include Sharia screening compliance will increase the creditability of financial information and hence attracting more investors. The paper employs a cross-sectional survey research design and depends mainly on primary data, which is collected through a structured questionnaire. To examine the accuracy of the data and conduct the analysis a number of statistical methods including the Kaiser-Meyer-Olkin (KMO), Bartlett's Test of Sphericity, Exploratory Factor Analysis (EFA) Confirmatory Factor Analysis (CFA), and Structural Estimation Modeling (SEM) are employed. The analysis supports the hypotheses set by the study and reveals the readiness of Sudanese stakeholders to accept applying the Sharia screening Criteria and their belief in the notion that the present screening criteria are effective in controlling Sharia impermissible economic activities and the ability of external auditors to identify and report on their customers' compliance with screening criteria.
\end{abstract}

Keywords: Islamic market index, Sharia compliant, Sharia Screening, standardization, financial ratios

\section{Introduction}

Currently, the area of Islamic banking and finance is blossoming; its growth has been remarkable in terms of the number of countries they invade, the domains of investment they cover, and the modes of finance they offer. It is expanding not only in countries with a majority Muslim population but also in those in which Muslims represent a minority. Seeking innovation and globalization different modes of Islamic finance are being offered by Islamic finance including cost-plus financing, profit sharing, leasing, partnership, forward sale contracts, deferred payment sale contracts, deferred-delivery sale contracts, and spot sale. Despite its small size, Islamic Finance has achieved tremendous growth in recent years. According to the International Monetary Fund (IMF) Islamic lenders have outperformed conventional banks over the past decade, and there is still a chance for growth. Thomson Reuters' 2018 Islamic Finance Development Report estimates that Sharia-compliant financial assets are forecasted to reach $\$ 3.8$ trillion by 2023 , averaging an annual growth of 10 percent. (https://ceif.iba.edu.pk/pdf/Reuters-Islamic-finance-development-report2018.pdf). One of the areas that have effected this growth is the investment in international stock markets. An average growth rate of approximately 8\% per annum is reported by Thomson Reuters, with the Islamic funds' assets under management expected to stand at USD 88 billion by 2020 .

A lot of individual and institutional Muslim investors are keen to invest only in stocks that are sharia compliant. So to meet the above mentioned increasing demand and attract more Muslim investors, different index providers started to develop their Islamic indices based on the Sharia screening methodology, which is set on two primary levels: industry activity and financial ratios. Activity screening is used to check the level of compliance of sharia compliant businesses with the provisions of sharia on the basis of their functions or activities. Companies that 
engage in prohibited activities such as financial transactions involving Riba (interest), alcoholic industry, gambling, weapon trading, and pork industry are deemed non-compliant by Sharia law. At the financial ratios' level, four financial ratios are employed to screen the sharia compliance, namely, the liquidity ratio, debt ratio, interest ratio, and non-permissible income ratio. The liquidity ratio is the proportion of liquid assets to total assets, the debt ratio shows the proportion of the company's operations that are financed by non-sharia compliant financing modes, the interest ratio measures interest as a percentage of total revenue, and the non-permissible income ratio is the ratio of a company's income derived from prohibited activities to its total income. Though at the level of industry activity minor or no discrepancies appear in selecting a compliant company by different indices, marked differences are noticed when using the financial ratios as an indicator. Islamic market indices such as Dow Jones Islamic Market Indices (DJIM), FTSE Sharia Global Equity Index Series, Standards and Poor's S\&P 500 Sharia Index, Morgan Stanley Capital International Global Islamic Indices (MSCI), and Karachi Meezan 30 Index Islamic Market Index (KMI30) use different methodologies for calculating their ratios. For instance, DJIM and S\&P use market capitalization as the denominator to calculate their ratios, while others, FTSE and MSCI are examples, use total assets. Further, the majority of the indices adopt a maximum of $33 \%$ for the debt and interest ratios, which has been and is still a subject of extensive criticism.

The problem of having different screening criteria and the importance of harmonizing them have been addressed by a number of authors, including Khatkhatay and Nisar (2007), Derigs and Marzban (2008), Sukri (2012), Ho (2015), Gamaleldin (2015), and Ayedh et al. (2019). However, neither a satisfactory description of the rationale behind the financial ratios has been given nor a solution for the long lasting issue of the need for harmonization has been provided. Nonetheless, the different screening indexes are being implemented by different countries, whether in the Islamic world or otherwise.

In Sudan, in 2003 a resolution by the Islamic Fiqh Academy to accept taking conventional loans to finance certain sectors has been issued. These sectors include water, electricity and power, armed forces, dams, and life-saving medicines. As such Sharia scholars and regulators have allowed local institutions to borrow conventional loans from abroad. Accordingly, this has rendered some investment activities within a fully Islamized financial system to include permissible and non-permissible undertakings. Despite this fact, Sudan has not yet deployed the Screening Criteria to cater to the compliance issues. Thus this paper aims at assessing the possibility of applying Sharia screening criteria in the Sudanese corporate sector and investigates the possibility of expanding the external Auditors' role to include reporting on Sharia compliance of corporate activities.

The rest of this paper is organized as follows: Section two is a review of the literature concerning the screening procedure and its adoption. Section three describes the methodology followed and the methods of analysis employed. Section four presents the empirical results and their discussion. Section five provides a summary and concluding remarks.

\section{Literature Review}

The screening methodology is defined as the benchmarks or standards of tolerance level of non-halal elements that are allowed to be mixed within an investment and the investment is still deemed as sharia compliant (Ching, 2012). These methodologies are an attempt to avoid excessive exposure to Riba. Sharia Screening is a relatively new feature of Islamic finance. Muslims generally have been reluctant to participate in equity markets due to the Sharia prohibition of participation in capital markets activities. In the 1990s, a major breakthrough took place in a religious ruling pertaining to equity investment. The International Islamic Fiqh Academy has issued Resolution No 63 in 1992, which has approved trading in common stocks of companies that do not engage in activities that violate Sharia principles. To ensure that the investment portfolio is in harmony with those conditions, Sharia screening procedures are developed. These procedures are classified into two categories; qualitative criteria or sector screening, which is concerned with the type of business in which the company is involved, and the financial screening that aims at excluding companies with unacceptable levels of conventional debt, liquidity, interest-based investment, and or impure income. The key references for the screening methodologies are the Quran and Sunna. Qualitative screening is used to screen non-permissible business activities according to Sharia guidelines principles. Sharia clearly demarcates a number of business activities that are not permissible for Muslims, such as investment in alcoholic beverages and products, pork and pork-related products, gambling, weapons, tobacco, and conventional banks and insurance companies. Thus at the level of industry activity negligible or, no differences appear in selecting a compliant company by different Sharia scholars or boards. Quantitative screens, on the other hand, are financial ratios that are compared to maximum allowable threshold levels. The reason for adopting quantitative screening in addition to qualitative screening is the fact it is necessary to investigate to what extent companies are involved in Sharia impermissible practices such as trading of money for money and transactions that are interest based. In today's modern financial world it is almost 
impossible to find any company that is not involved in transactions encompassing interest receipt or payments. Unlike qualitative criteria which are clearly stated in the Holy Quran and the Sunnah, these Sharia sources do not explicitly state the guidelines for the quantitative criteria. Further, the difficulty of transforming verbal Sharia sources into quantifiable and formal guidelines to be used poses another difficulty in setting agreed upon quantitative standards. Determination of the thresholds for financial ratios, thus, is based on reasoning and inferences from the sources of Sharia by qualified Sharia scholars, this is referred to as Ijtihad. Ijtihad gives scholars some degree of freedom to specify their quantitative criteria and accordingly screening guidelines and strategies vary among Sharia scholars and over time.

\subsection{Financial Screening Ratios}

Financial Screening Ratios focus on different aspects of an investment, namely, liquidity, interest, debt, and non-permissible income. Each Sharia Board or index uses a set of ratios for screening the assets and an asset is considered compliant if it meets all the screens included in the set. Initially, Sharia scholars had set their guidelines back in 1987, which articulate that total debts should be less than $33 \%$ of the equity, account receivable should be less than $49 \%$ of total assets and interest income from cash and interest should not be more than $5 \%$ of the total income. However, recently benchmarks tend to vary from one Sharia index to another. According to the Accounting and Auditing Organization for Islamic Financial Institution (AAOIFI), these ratios are the Interest based debt, Interest based deposit, Earning from impermissible activities, and Tangible assets and benefits. The interest-based debt measures the amount of interest raised on loans, whether long term or short term, and it should not exceed $30 \%$ of the market capitalization of the corporation. The interest based deposit is an indicator of the total amount of interest on deposits, whether short, medium, or long term, and shall not exceed 30\% of the market capitalization of total equity. As regarding the earning from impermissible activities the amount of income generated from prohibited activities should not exceed 5\% of the total income of the corporation. The tangible assets and benefits ratio asserts that the total market value of tangible assets, benefits, and rights should not be less than $30 \%$ of the total asset value of the corporation. The justification of the $30 \%$ threshold criterion applied to quantitative screening level is Hadith Ibn Saad Ibn Abi Waqqas "one-third is big". Ibn Saad reported that his father says: Prophet Mohamed (May peace be upon him) visited me during my illness. I said: Allah's Messenger, you can well see the pain with which I am afflicted and I am a man possessing wealth, and there is nobody to inherit me except only one daughter, should I give two-thirds of my property as Sadaqa (charity)? He said: No. I said: Should I give half (of my property) as Sadaqa? He said: No. He (further) said: Give one third (in charity) and that is quite enough. Though Islamic index providers have used the maximum threshold criterion of $33 \%$ by relying on this hadith as a justification, one-third has been interpreted and implemented as ranging from $30 \%$ to $37 \%$. Further, the concept of wealth is considered either as total assets or market capitalization. These differences in interpretations are considered as the origin of dissimilarities between different Islamic indexes.

\subsection{Leading Sharia Indexes Financial Ratios}

Though it is not clear exactly when the first Islamic index is established, it is obviously associated with the introduction of Islamic funds such as Amana Income Fund and Islamic equity funds issued by the national commercial bank of Saudi Arabia and Dallah Al Baraka. Since then Islamic equity funds have been provided by many financial institutions, but there is no Islamic index to help rank funds' performance. According to Siddiqui, (2009) the first Islamic index has been constructed and launched by Dow Jones in February 1999, the Dow Jones Islamic Market (DJIM) Index. The DJIM screens have been adopted by the Accounting and Auditing Organization for Islamic Financial Institutions (AAOIFI) Standard 21. The index series includes more than 70 indices and is the most comprehensive Islamic market index that provides approximately $95 \%$ market coverage of 44 countries. The ratios adopted by DJIM Index use the market capitalization as a base. Debt ratio is measured as debt divided by 24 months average market capitalization and should be less than 33\%, Account Receivables ratio is calculated as accounts receivables plus cash dividend by 24 months average market capitalization and should be less than 33\%, Revenue from impermissible activities ratio is determined by dividing revenue from impermissible activities plus total interest by average market capitalization and should be less than $5 \%$ and Cash plus Interest Bearing Items ratio is defined as cash plus interest bearing items divided by 24 months average market capitalization and should be less than 33\%. Another international Islamic Index is the FTSE Global Islamic Index Series, which has been created in 1999. Unlike other screening methodologies, FTSE adopts a more conservative approach to Sharia compliance by measuring debt ratio as a percentage of total assets, rather than a percentage of the more volatile measure that uses average market capitalization. The financial ratios set by FTSE are: Debt should be less than 33.33\% of total assets; Cash and interest bearing items are less than 33.33\% of total assets; Accounts receivable and cash are less than 50\% of total assets, and Total interest and 
non-compliant activities income should not exceed 5\% of total revenue. Standard \&Poor's introduces S\&P Sharia Indices in 2006 to meet the increasing demand for Sharia compliant stocks. The financial screening ratios used by S\&P are Liquidity Ratio, which should be less than $49 \%$ of account receivable divided by 36 months average market capital, Cash plus Interest bearing securities divided by 36 months average market capital should be less than 33\%, Debt Ratio should be less than 33\% of total debt divided by 36 months average market capital, and Revenue from impermissible activities plus Total Interest divided by 36 months average market capitalization should be less than 5\%. Morgan Stanley Capital International World Islamic Indices (MSCI) establishes in March 2007 a global family of Islamic indices, designed to reflect Sharia investment principles. The indices are calculated according to the MSCI Global Investable Market Indices Methodology and reviewed by MSCI Sharia advisors for ongoing compliance with the MSCI Islamic Index Series. Quantitative screens used include Debt ratio calculated as debt divided by total assets, which should be less than $33.33 \%$, Accounts Receivable ratio calculated as account receivables plus cash divided by total assets and should be less than $70 \%$. Revenue from impermissible activities plus total interest divided by total assets should be less than 5\%, and Cash plus Interest Bearing Items divided by total assets should be less than 33.33\%. Thompson Reuters Ideal Ratings Islamic Indices have been provided by Sharia Fund Management Services for Financial Institutions since 2006. The indices currently cover 20 countries and regions. Its quantitative screening is conducted by using Debt ratio measured as total debt to trailing 12-month average market capitalization and should be less than $30 \%$; the ratio of Cash, Deposits, and Interest bearing investment to total assets, which should less than 30\%; and the ratio of Cash, Deposits, and Receivables to total assets, which should be less than $67 \%$.

Thus it is clear from the above review that some dissimilarities do exist between the quantitative financial screens used by the different Islamic funds and index providers. The main differences are the use of market capitalization versus total assets as a ratio divisor and the range of threshold values. Supporters of the use of market capitalization argue that it reflects the real worth of a company and the use of the trailing average evens the measure and eliminates any seasonality effects. Further, the market capitalization as a base enables continuous sharia screening, since market capitalization can be calculated from market prices at any point in time, whereas Sharia compliance screening can be conducted only when detailed financial statements are published if total assets are chosen as a ratio divisor. Another cited advantage of using market capitalization rather than total assets is that different accounting methods are employed in the preparation of financial information, such as inventory valuation and depreciation methods. This may lead to an inconsistent valuation of assets across companies and for the same company over time and accordingly result in misleading Sharia screening. On the other hand, those who favor the use of total assets as a divisor consider it as being an appropriate measure that meets the generally accepted accounting principles and that it is shielded from external market influences or speculations. Regarding the threshold values used to measure the liquidity level of companies a large threshold dispersion, ranging from 33 to 80 percent, is found among the different screening indexes. A liquidity threshold of 33 percent is used in the liquidity screens of Dow Jones, whereas it ranges between 45 percent and 50 percent for the FTSE and S\&P and 70 percent for MSCI.

Every one of these indices has its clarification for the threshold it uses as a base. The threshold of 33 percent is based on the Hadith "one-third is too much", which is interpreted from the point of view of the Sharia boards as a portion of less than one-third is to be insignificant. Supporters of the liquidity threshold between 45 percent and 50 percent are of the opinion that since the portion of illiquid assets has to be larger than the portion of liquid assets, then liquid assets larger than 50 percent of the total assets or market capitalization, is considered permissible. This is based on the juristic principle: "The majority deserves to be treated as the whole". The 70 percent ratio is justified by the same Hadith "one-third is too much", which is interpreted in a reverse way; since "one-third is too much" then two-thirds is permissible. The Liquidity threshold of more than 80 percent, which is used only by Al Meezan Investments in Pakistan, is based on the opinion that the illiquid portion of total assets should be an insignificant quantity; Less than $25 \%$ (https://www.almeezangroup.com/investor-education/shariah-methodology/). The total interest and non-compliant activities income threshold of 5\% of total revenue have no real foundation in the holy Quran or Hadith. It is mainly founded on the principle of Ijtihad of Sharia scholars and is based on the fact that since Islamic investors have no control over the whole business practices of companies they invest in, it is agreed that the portion of non-compliant income is to be considered as negligible if it does not exceed 5 percent of the total revenue generated.

\subsection{Attempts of Standardization}

The problem of having different screening criteria and the importance of harmonizing them have been addressed by a number of authors including Khalaf and Tett (2007), Khatkhatay and Nisar (2007), Derigs and Marzban 
(2008), Ghoul (2008), Donia (2010), Oakley (2010), Sukri (2012), Ho (2015) and Gamaleldin (2015). According to these studies, non-standardization has obstructed innovation, generated ambiguity regarding Islamic product design, and hindered Islamic equity market growth. Further lack of standardization has resulted in ununified Islamic governance models, which in turn leads to different measures of compliance and increases the risk of fatwa shopping by Sharia boards. Reasons cited for Non-standardization include immaturity of the Islamic finance industry, recency of Sharia screening methodology, absence of universal or generally accepted understanding of how to transform the descriptive Sharia rules into quantifiable investment guidelines, Lack of globally acceptable Islamic standards, and credible independent universal Sharia authority, and diverse legal frameworks and regulations.

Though research has pinpointed the crucial need for having a unified and standardized screening framework, no attempts have been made to offer a revised version of a Sharia screening methodology. This is mainly due to the fact that the screening process, especially financial screening and the tolerance level cannot be linked directly to the main sources of Islamic rules, namely the Quran and Sunna. Since Sharia screening is based on Ijtihad it is more likely to be susceptible to subjective views and hence differences and discrepancies. Further, a number of researchers who examine the level of disparity between ratings of sharia compliant stocks by various index providers report a narrow range of differences. According to Derigs and Marzban (2008), the criteria providers have differed in classifying the sharia compliant status of $28 \%$ of their sample stocks. Abdulrahman et al. (2010), examines the level of disparity between the Kuala Lumpur Stock Exchange Sharia Index (KLSESI) and the Dow Jones Islamic Market Index (DJIM) and find that $21 \%$ of Malaysian companies that are approved by the Sharia Advisory Council (SAC) of KLSESI as sharia compliant do not conform to the standards of DJIM. Pok (2012) documents that only $12 \%$ of Malaysian companies are qualified as Sharia compliant under the DJIM criteria, whereas $16.8 \%$ are qualified under the S\&P criteria. Under the FTSE criteria compared to KLSESI the difference amounts to $37 \%$. One major reason for the existence of variations relates to the divisor used to calculate the screening ratios. S\&P and Dow Jones use average market capitalization as a divisor and both use almost similar ratios and thresholds levels and this is why the differences between them are almost negligible, less than 5\% percent. On the other hand, comparing Dow Jones or S\&P to indexes that use total assets as a divisor, KLSESI, and FTSE, an average variation of about 28 percent is reported.

Thus it would be an exaggeration to infer that the inconsistency or lack of standardization in Sharia screening norms and practices could be considered as a hindrance to the adoption or growth of Islamic finance. Islamic law has nurtured a tradition of diversity and disagreement, which is referred to as Ikhtilaf. Ikhtilaf on religious issues has been a common phenomenon in the Muslim community as a result of their different judgments and perceptions on various matters. Such diversity is permissible as long as it does not violate the basic principles of Islam. A number of Muslim Imams including Ibn Qudamah and Ibn al-Arabi state that the difference in Islamic judgments is broad mercy due to the ease that results from it (http://alwaeialshababy.com/ar/index.php/our-religion/13933-2019-02-11-19-16-59). The existence of Ikhtilaf permits Muslims to choose the interpretation of religious teachings that fit their own beliefs and circumstances and cause no harm to them or to others. In addition, the Hadith of Prophet Muhammed "Take a fatwa from your heart, even if people advise you to take a different one" gives Muslims room to decide on which interpretation of Islamic teachings to follow. Consequently, Islamic investors have a menu of Sharia screening methodologies from which to choose without a feeling of bewilderment or sin.

The wide coverage by Islamic indexes, for instance, the S\&P 500 Sharia and Dow Jones Islamic Market World Index represent about one-half of the total market capitalization of their conventional benchmark indices, lead this study to develop the following hypotheses:

Hypothesis one: Sudanese stakeholders do accept applying Screening Criteria as part of the compliance methodologies to cater to companies with mixed activities

Hypothesis two: Sudanese stakeholders consider available Screening Criteria as effective and robust in the control of Sharia impermissible economic activities.

Hypothesis three: Extending the role of external auditors to include screening compliance in the audit report will increase and sustain investors' confidence in the purification of Sharia compliant companies' activities.

\section{Methods}

To test the hypotheses set the paper employs a cross-sectional survey research design and depends mainly on primary data, which is collected through a structured questionnaire. The targeted population is the participants at Khartoum Stock Exchange (KSE), including investors, brokers, officers, and regulators; Islamic Figh Academy officers and scholars; independent Sharia scholars; Bank of Sudan (BOS) officials, Auditor General (AG), and 
Accounting and Auditing Organizing Council (AAPOC). One hundred questionnaires have been distributed, each of which contains thirty-three variables, bringing the sample size to 2,475 observations. The questionnaire consists of four sections. The first section requested the respondents to provide personal background information. The second section contains statements that are used to assess whether the Sudanese stakeholders accept applying Sharia Screening Criteria to investigate to what extent companies are involved in Sharia impermissible practices. Section three comprises statements that refer to Sudanese stakeholders' opinions about the effectiveness of available Screening Criteria as robust in the control of Sharia impermissible economic activities. All statements are responded to using a five-point Likert scale from 1 (strongly disagree) to 5 (strongly agree).

To examine the accuracy of the data descriptive statistics is employed; a check is made for normality via ascertaining Skewness and Kurtosis of latent factors and other variables. Exploratory Factor Analysis (EFA) EFA is used to yield a 'clean' pattern matrix and extract factors as well as generating key outputs, whereas Confirmatory Factor Analysis (CFA) is used to test the adequacy of the model. The three measures used to determine whether the sample is adequate to proceed with factor analysis are sample size, which should be 100 or larger; factorability of the correlation matrix, which is to be assumed; the Kaiser-Meyer-Olkin (KMO) measure of sampling adequacy, which should be greater than 0.6; and Bartlett's Test of Sphericity (BTS), which is significant at $\alpha<.01$ ). The communalities that represent the proportion of variance of each variable that is explained by the factors are calculated and the minimum value is set at 0.30 . The Structural Estimation Model (SEM) is used to test the hypotheses. The statistical package SPSS24 and SEM software Analysis of Moment Structures (AMOS) are employed for conducting the statistical analysis. The research uses Cronbach's alpha test as a reliability testing technique. Cronbach's alpha reliability coefficient normally ranges between 0 and 1 . The closer Cronbach's alpha coefficient is to 1.0 the greater the internal consistency of the items in the scale. The Root Mean Square Error of Approximation (RMSEA), the Comparative Fit Index (CFI), the Chi-square statistics (CMIN), the Degree of Freedom (DF), and the Standardized Root Mean Square Residual (SRMR) are employed as measures of model fit

\section{Results and Discussion}

The checks for multivariate normality by determining skewness and kurtosis fairly assert the normal distribution of the latent factors and all other variables. Using Maximum Likelihood as an iterative estimation method, the summary of results shown in Table 1 below indicates the suitability of data for structure detection. The Kaiser-Meyer-Olkin Measure of Sampling Adequacy has a value of 0.7 for all the variables pertaining to the three hypotheses and Bartlett's test of sphericity reveals small values (less than 0.01) of the significance level indicating that the factor analysis is appropriate for the research data.

Table 1. KMO and Bartlett's measure of sample adequacy

\begin{tabular}{llccc}
\hline & & Hypothesis (1) & Hypothesis (2) & Hypothesis (3) \\
\hline Kaiser-Meyer-Olkin Measure & & 0.694 & 0.704 & 0.739 \\
Bartlett's Test of Sphericity & Approx. Chi-Square & 299.744 & 199.200 & 563.152 \\
& DF & 55 & 45 & 66 \\
& Sig. & 0.000 & 0.000 & 0.000 \\
\hline
\end{tabular}

The initial communalities and extraction communalities for all variables shown in appendix (A) indicate that most extractions are above the minimum value of 0.30 , those below the target are subject to elimination. Thus the remaining variables do fit well with the factor analysis.

The paper utilizes the AMOS (Analysis of Moment Structures) software package to test the model fit for each latent variable and the entire data set to develop a complete measurement model before moving into the Structural Equation Modelling (SEM). To assess the degree of relationship between the observed indicator variables and the underlying constructs that are designed to measure it, that is, the relationship between the observed and unobserved variables, CFA has been conceptualized and tested for its psychometric properties. The measurement model, then, represents the CFA model and specifies the pattern by which each measure loads on a particular factor. Figure 1 displays the measurement model developed. Numbers at top of Qs are the factors' variances, numbers above the arrows are the regression betas' coefficients and circles are for latent variables. The readings in Figure1 of the Root Mean Square Error of Approximation (RMSEA) and the Comparative Fit Index (CFI) are within the specified acceptable levels. To assess the model fit measures of good fitness have been calculated and presented in Table 2. These include Chi-square statistics (CMIN), Root Mean Square Error Approximation (RMSEA), Degree of Freedom (DF), Comparative Fit Index (CFI), and Standardized Root Mean 
Square Residual (SRMR). The calculated measures are within the specified thresholds, thus confirming the model fitness.

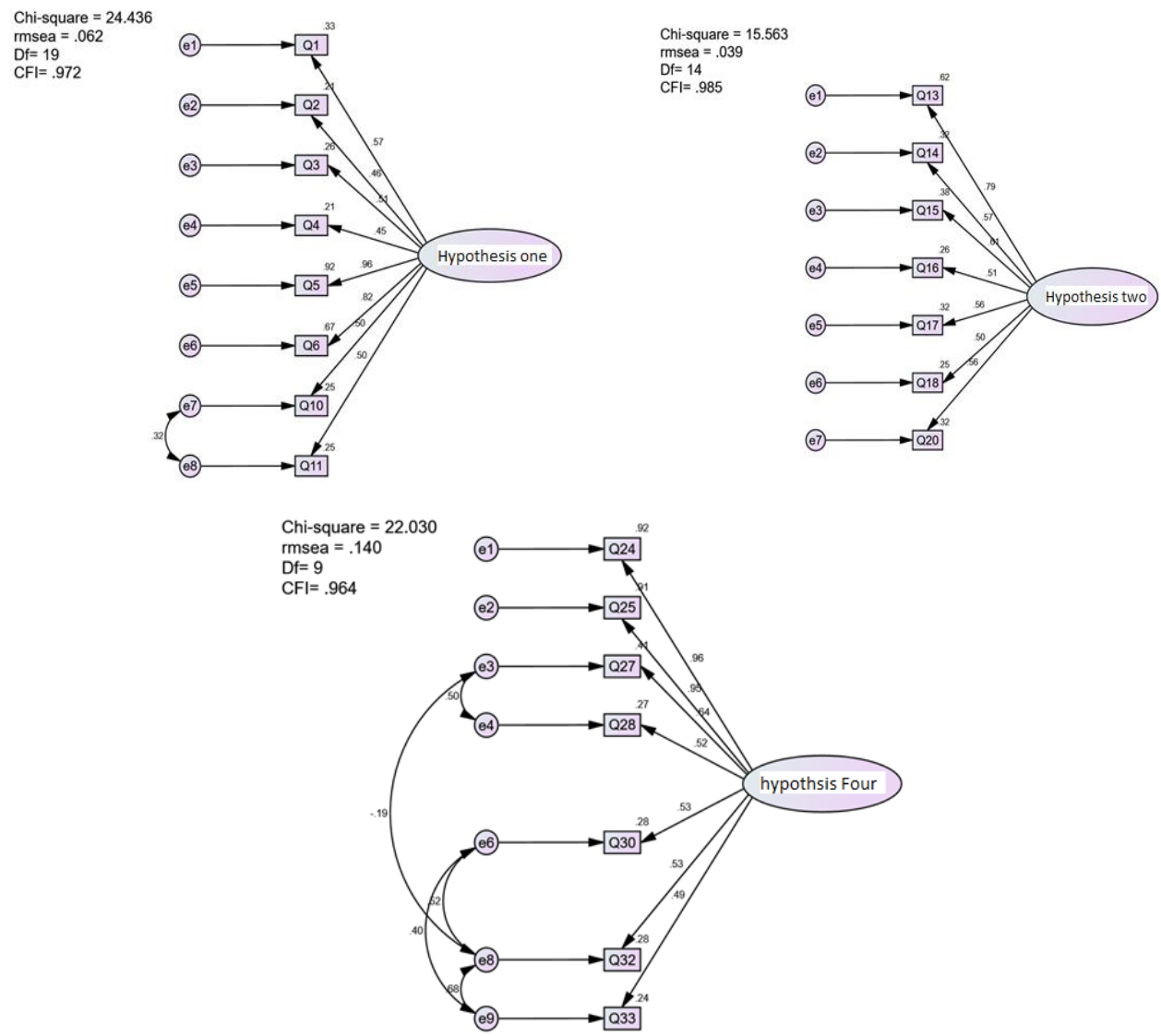

Figure 1. Measurement model

Table 2. Validity measures of the measurement Model

\begin{tabular}{lcccc}
\hline Measure & $\begin{array}{c}\text { Estimates For } \\
\text { Hypothesis One }\end{array}$ & $\begin{array}{c}\text { Estimates For } \\
\text { Hypothesis Two }\end{array}$ & $\begin{array}{c}\text { Estimates For } \\
\text { Hypothesis Three }\end{array}$ & Threshold \\
\hline CMIN & 24.436 & 15.563 & 22.030 & 9 \\
DF & 19 & 14 & 0.853 & 0.7 \\
Cronbach's Alpha & 0.722 & 0.734 & 0.852 & $\geq 0.7$ \\
CR & 0.823 & 0.787 & 0.472 & 0.5 \\
VE & 0.386 & 0.351 & 2.448 & Between 1 and 3 \\
CMIN/DF & 1.286 & 1.112 & 0.964 & $>0.95$ \\
CFI & 0.972 & 0.985 & 0.067 & $<0.08$ \\
SRMR & 0.070 & 0.066 & 0.110 & $0.01-0.08$ \\
RMSEA & 0.062 & 0.039 & & \\
\hline
\end{tabular}

Table 2 summarizes the measures of the models good fit for data. It is clear from the table that all the validity measures for the hypothesized models are significant. The Cronbach's $\alpha$ for all the latent variables of the three hypotheses is around 0.7, the construct reliability (CR) for all the latent variables is more than 0.7, the Variance Extracted (VE) though is less than 0.5 but it is acceptable since according to Fornell and Larcker (1981) if VE is less than 0.5 , but the composite reliability is higher than 0.6 , then the convergent validity of the construct is still adequate. The Minimum Discrepancy divided by its Degrees of Freedom (CMIN/DF) ranges between 1.3 and 2.4, the Comparative Fit Index (CFI) is above 0.95, the Standardized Root Mean Residual (SRMR) is around 0.7, and the Root Mean Square Error of Approximation (RMSEA) ranges between 0.03 and 0.1. Though 0.08 indicates a mediocre fit for RMSEA, some go up to 0.10 for mediocre (Maydeu-Olivares et al., 2018). Thus all the measures indicate that the study can proceed to develop the structural model. 
The structural model depicted in Figure 2 shows the structural paths and estimations of parameters for the structural model. It is observed that all the structural model fit indices are not only significant but remain the same as in the measurement model. The measures of RMSEA, CFI, and Chi-Square are 0.62, 0.972, and 24.436 respectively for hypothesis one factors; $0.039,0.985$, and 15,563 respectively for hypothesis two factors, and $0.140,0.964$, and 22.030 respectively for hypothesis three factors. The measurement accuracy for each latent variable is evaluated by the factor loadings and error variances for the observed items in the structural model. The standardized factor loadings for all items, with the exception of two relating to hypothesis three, were above the suggested cut-off of 0.50 . The analysis of all the observed variables of hypothesis one shows that more than $50 \%$ of the variance is explained by latent variables for the majority of items. The only exceptions are Q1 and Q10 where $77 \%$ and $59 \%$ of their variance is explained by other factors respectively. As for hypothesis two around $78 \%$ of the variance is explained by latent variables. The analysis of the items in hypothesis three reveals, with the exception of Q28 and Q30 more than 60\% of the variance is explained by the latent variables.

Table 3 presents the structural relations and related statistics for the structural model. The measures shown justifies the model fit. The positive coefficient estimates and their $\mathrm{P}$ values indicate a positive and significant relationship between the study variables and the large values of CR prove that path is significant at the 0.05 level, that is, the estimated path parameters are significant.

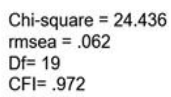

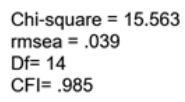
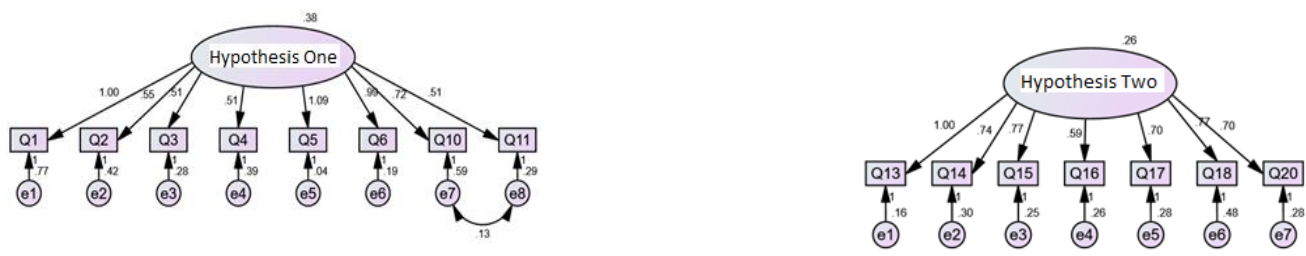

Chi-square $=22.030$

rmsea $=.140$

$\mathrm{Df}=9$
$\mathrm{CFI}=.964$

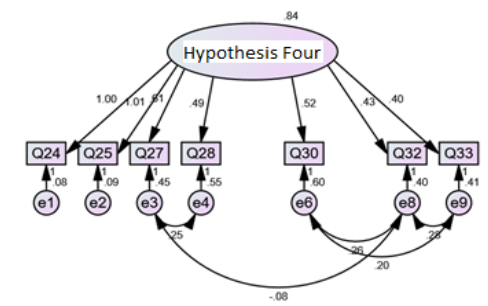

Figure 2. The structural model

Table 3. Structural relations and related statistics for structural model

\begin{tabular}{|c|c|c|c|c|c|c|}
\hline & & & Coefficients Estimate & S.E. & C.R. & $\mathrm{P}$ \\
\hline Q1 & $<---$ & hypothesis one & 1.000 & & & \\
\hline Q2 & $<---$ & hypothesis one & .545 & .157 & 3.475 & $* * *$ \\
\hline Q3 & $<---$ & hypothesis one & .509 & .135 & 3.774 & $* * *$ \\
\hline Q4 & $<---$ & hypothesis one & .515 & .152 & 3.384 & $* * *$ \\
\hline Q5 & $<---$ & hypothesis one & 1.088 & .198 & 5.488 & $* * *$ \\
\hline Q6 & $<--$ & hypothesis one & .990 & .191 & 5.185 & $* * *$ \\
\hline Q10 & $<---$ & hypothesis one & .718 & .194 & 3.692 & $* * *$ \\
\hline Q11 & $<---$ & hypothesis one & .507 & .138 & 3.680 & $* * *$ \\
\hline Q13 & $<---$ & Hypothesis two & 1.000 & & & \\
\hline Q14 & $<---$ & Hypothesis two & .737 & .159 & 4.629 & $* * *$ \\
\hline
\end{tabular}




\begin{tabular}{|c|c|c|c|c|c|c|}
\hline & & & Coefficients Estimate & S.E. & C.R. & $\mathrm{P}$ \\
\hline Q15 & $<---$ & Hypothesis two & .768 & .170 & 4.506 & $* * *$ \\
\hline Q16 & $<---$ & Hypothesis two & .589 & .160 & 3.688 & $* * *$ \\
\hline Q17 & $<---$ & Hypothesis two & .702 & .175 & 4.014 & $* * *$ \\
\hline Q18 & $<---$ & Hypothesis two & .775 & .202 & 3.835 & $* * *$ \\
\hline Q20 & $<--$ & Hypothesis two & .697 & .156 & 4.453 & *** \\
\hline Q24 & $<---$ & Hypothesis four & 1.000 & & & \\
\hline Q25 & $<--$ & Hypothesis three & 1.009 & .067 & 15.016 & $* * *$ \\
\hline Q27 & $<---$ & Hypothesis three & .607 & .092 & 6.579 & $* * *$ \\
\hline Q28 & $<--$ & Hypothesis four & .494 & .103 & 4.807 & $* * *$ \\
\hline Q30 & $<--$ & Hypothesis four & .523 & .102 & 5.109 & $* * *$ \\
\hline Q32 & $<---$ & Hypothesis four & .430 & .084 & 5.110 & $* * *$ \\
\hline Q33 & $<---$ & Hypothesis four & .400 & .086 & 4.666 & *** \\
\hline
\end{tabular}

***: P is Significant at .05 level, NS: Not Significant.

It is clear from the analysis that there is a statistically significant relationship between the observed and unobserved variables and among the unobserved variables. The evidence from the structural model reveals is a statistically significant relationship between the readiness of Sudanese stakeholders to accept applying the Sharia screening Criteria and the belief that the screening criteria is capable of providing more information to investors and additional economic benefits to Sharia-compliant companies. Further, the impact of awareness of market participants of the Sharia screening criteria and the existence of non-permissible investment activities within the economy is also a significant one. Also, the model asserts a positive relationship between acceptance of the sharia screening criteria and attraction of foreign investments.

As regarding the effectiveness and robustness of available screening criteria in controlling Sharia impermissible economic activities, the results indicate that there is a strong positive relation between considering available Screening Criteria as effective and robust and the credence that screening criteria are an essential part of the Sharia compliance process. Also, the impact of attracting foreign Islamic investors is found to be high. In addition, the capability of Sudanese Sharia regulators to apply screening criteria and its reasonable cost, as well as the dominant Islamic culture of the Sudanese community, play an important role in considering the Sharia screening criteria as an effective tool in monitoring activities of Sharia-compliant companies.

The factors that positively affect extending the role of external auditors to include screening compliance in the audit report are the ability of certified public accountants to identify and report on their customers' compliance with screening criteria, the notion that external auditor report will complement rather than substitute Sharia reports issued by other Sharia authorities, the credibility of Accounting and Auditing Organization as a provider of necessary regulations, increased dependence on audited financial statements for investment decision-making purposes, and the usage of financial accounting statements by KSE as the main source of information of companies performance.

\section{Conclusions}

The remarkable growth of Islamic finance and its expansion not only in countries with majority Muslim population but also in those in which Muslims represent a minority has led the International Islamic Fiqh Academy to issue a resolution approving trading in common stocks of companies that do not engage in activities that violate Sharia principles. Since a lot of individual and institutional Muslim investors are keen to invest only in stocks that are sharia compliant, different index providers started to develop their Islamic indices based on the Sharia screening methodology. Despite the noticeable worldwide usage of this methodology, Sudan has not yet deployed the Sharia screening criteria to cater to the compliance issues, especially after a decision made by the Islamic Fiqh Academy allowing taking conventional loans to finance certain economic sectors. Thus this paper aims at assessing the possibility of applying Sharia screening criteria in the Sudanese corporate sector and investigating the possibility of expanding the external Auditors' role to include reporting on Sharia compliance of corporate activities. To examine the accuracy of the data and conduct the analysis a number of statistical methods are employed, including the Cronbach's alpha test, the Kaiser-Meyer-Olkin (KMO) measure, Bartlett's Test of Sphericity (BTS), the Exploratory Factor Analysis (EFA), the Confirmatory Factor Analysis (CFA) and Structural Estimation Modeling (SEM). The statistical package SPSS24 and SEM software Analysis of Moment Structures (AMOS) are employed for conducting the statistical analysis. 
The evidence documents by the paper indicate the strong will of the Sudanese stakeholders to accept applying the Sharia screening Criteria and their belief that the screening criteria is effective in monitoring and controlling Sharia impermissible economic activities. Further extending the role of external auditors to include screening compliance in the audit report is considered to have a positive impact on investors' confidence in the purification of Sharia compliant companies' activities. These results are justifiable on the basis that market participants in a country with a dominant Islamic culture like Sudan will be deeply concerned about the adherence of companies they invest into Sharia rulings. Screening measures are an integral part of the Sharia compliance standards. They will provide more information to investors and additional economic benefits to Sharia-compliant companies by attracting more investment. In addition, reporting by external auditors on screening compliance will add to the creditability of the financial information presented in the financial statements. Furthermore, since the external auditor report will complement rather than substitute Sharia reports issued by other Sharia authorities, this will furnish investors with two independent sources of information and increase the confidence of market participants. The results are also in line with the paper's viewpoint that the inconsistency or lack of standardization in Sharia screening norms and practices is not expected to hinder or delay the adoption or growth of Islamic finance.

Based on the findings of the study it is recommended that Sharia screening methodology should be implemented through enacting laws and regulations. The screening criteria methodology issued by the AAOIFI can be chosen since Sudan has already adopted AAOIFI Sharia Accounting Standards for Islamic banks. This is more likely to close the gap observed between the guidelines and strategies followed by different Sharia boards. The country can benefit from the experience of other countries that precede it in this area, such as using software programs that are able to differentiate between compliant and non-compliant securities and establishing a central local authority that is responsible for the declaration and announcement of securities' compliance. Further assessment on income purification is suggested to be part of Sharia screening assessment criteria. This can be achieved through reporting on donations or charity to which non-permissible income generated has been channeled. Moreover, it is recommended that different Sharia screening standards could be set for different industries. Industries differ in nature and hence may require different evaluation standards. For instance, the life-saving medicine industry may require more lenient measures than the armed forces sector.

\section{References}

Abdul, R. A., Azlan, Y. M., \& Herry, M. (2010). Islamic norms for stock screening: A comparison between the Kuala Lumpur stock exchange Islamic index and the Dow Jones Islamic Market index. International Journal of Islamic and Middle Eastern Finance and Management, 3(3), 228-240. https://doi.org/10.1108/17538391011072426

Adam, N. L., \& Abu, B. N. (2014). Shariah Screening Process in Malaysia. Procedia - Social and Behavioral Sciences, 121, 113-123. https://doi.org/10.1016/j.sbspro.2014.01.1113

Ahmed, A. A., \& Habib, F. (2017). Revisiting the AAOIFI Shari'ah standards' stock screening. International Journal of Business and Society, 18(1), 151-166.

Ayedh, A. M., Kamaruddin, M. I., \& Shaharuddin, A. (2019). Sharia Screening Methodology: Does It 'Really' Sharia Compliance? IQTISHADIA, 12(2), 144-172. https://doi.org/10.21043/iqtishadia.v12i2.5573

Ayedh, A. M., Shaharuddin, A., \& Kamaruddin, M. I. (2020). Challenging the Current Shariah Screening Methodology Assessments in Kuala Lumpur Shariah Index (KLSI). International Journal of Academic Research in Accounting, Finance and Management Sciences, 9(4), 253-268. https://doi.org/10.6007/IJARAFMS/v9-i4/6844

Azmi, A., Non, N., \& Ab Aziz, N. (2017). Challenges to Sharia equity screening, from Sharia scholars' perspective. International Journal of Islamic and Middle Eastern Finance and Management, 10(2), 229-242. https://doi.org/10.1108/IMEFM-11-2016-0165

Byrne, B. M. (2010). Structural Equation Modeling with AMOS: Basic Concepts, Applications, and Programming (2nd ed.). Routledge/Taylor \& Francis Group.

Chen, F., Patrick, J., Curran, P., Bollen, K., Kirby, J., \& Paxton, P. (2008). An Empirical Evaluation of the Use of Fixed Cutoff Points in RMSEA Test Statistic in Structural Equation Models. Social Methods Research, 36(4), 462-494. https://doi.org/10.1177/0049124108314720

Choudhury, M. A., \& Hussain, M. M. (2005). A paradigm of Islamic money and banking. International Journal of Social Economics, 32(3), 203-217. https://doi.org/10.1108/03068290510580760

Derigs, U., \& Marzban, S. (2008). Review and analysis of current Sharia compliant equity screening practices. 
International Journal of Islamic Middle Eastern Finance and Management, 4, 285-303. https://doi.org/10.1108/17538390810919600

Derigs, U., \& Marzban, S. (2009). New strategies and a new paradigm for Shariah-compliant portfolio optimization. Journal of Banking and Finance, 33(6), 1166-1176. https://doi.org/10.1016/j.jbankfin.2008.12.011

El Khamlichi, A., Kabir, S., Arouri, M., \& Teulon, F. (2014). Are Islamic Equity Indices More Efficient Than Their Conventional Counterparts? Evidence from Major Global Index Families. Journal of Applied Business Research, 30(4), 1137-1150. https://doi.org/10.19030/jabr.v30i4.8660

Elhussein, N. (2012). Islamic finance: Is it a viable option to restrain financial crisis? Interdisciplinary Journal of Contemporary Research in Business, 5(4), 576-588.

Fornell, C., \& Larcker, D. (1981). Evaluating structural equation models with unobservable variables and measurement error. Journal of Marketing Research, 18(1), 39-50. https://doi.org/10.1177/002224378101800104

Gamaleldin, F. (2015). Shariah-Compliant Stocks Screening and Purification (pp. 1-44). doi:10.13140/RG.2.1.3063.0249

Hanif, M. (2018). Shariah-compliance ratings of the Islamic financial services industry: A quantitative approach. ISRA International Journal of Islamic Finance, 10(2), 162-184. https://doi.org/10.1108/JJIF-10-2017-0038

Hashim, A. M., Habib, F., Isaacs, Z., \& Gadhoum, M. (2017). ISRA-Bloomberg Sharī'ah stock screening and income cleansing methodologies: A conceptual paper. ISRA International Journal of Islamic Finance, 9(1), 27-42. https://doi.org/10.1108/IJIF-07-2017-004

Ho, C. S. F. (2015). International comparison of Sharia compliance screening standards. International Journal of Islamic and Middle Eastern Finance and Management, 8(2), 222-245. https://doi.org/10.1108/IMEFM-07-2014-0065

Htay, S. N., Abedeen, Z., \& Salman, S. A. (2013). Towards Standardization of Sharia Screening Norms and Practices. International Journal of Humanities and Social Science Invention, 2(11), 23-30.

Kabir, M. H., Rashid, M., Wei, A., S., Adedokun, B. O., \& Ramachandran, J. (2019). Islamic business scorecard and the screening of Islamic businesses in a cross-country setting. Thunderbird International Business Review, 61(3), 1-13. https://doi.org/10.1002/tie.22038

Kamali, M. (1998). The Scope of Diversity and "Ikhtilaf" (Juristic Disagreement) in the Sharia. Islamic Studies, 37(3), 315-337. Retrieved January 10, 2021 from http://www.jstor.org/stable/20837001

Kasi, U. (2018). Design, qualification and Sharia governance of stock screening methodologies in selected Gulf Cooperation Council (GCC) countries in comparison with the United States. Qualitative Research in Financial Markets, 10(2), 189-209. https://doi.org/10.1108/QRFM-04-2017-0039

Kasi, U., \& Muhammed, J. (2016). Strict and Uniform Shariah Screening Methodologies in Selected Asian Countries in Comparison with the United States. Asian Journal of Finance \& Accounting, 8(1), 38-76. https://doi.org/10.5296/ajfa.v8i1.8410

Maydeu-Olivares, A., Shi, D., \& Rosseel, Y. (2018). Assessing Fit in Structural Equation Models: A Monte-Carlo Evaluation of RMSEA Versus SRMR Confidence Intervals and Tests of Close Fit. Structural Equation Modeling: A Multidisciplinary Journal, 25(3), 389-402. http://doi.org/10.1080/10705511.2017.1389611

Nisar, S., \& Khatkhatay, M. H. (2006). Shari'a-compliant equity investments: an assessment of current screening norms. Proceedings of the Seventh Harvard University Forum on Islamic Finance. Harvard University, Cambridge, MA.

Obaidullah, M. (2001). Ethics and efficiency in Islamic stock markets. International Journal of Islamic Financial Services, 3(2), 1-10.

Pok, W. C. (2012). Analysis of Sharia quantitative screening norms among Malaysia Sharia compliant stocks. Investment Management and Financial Innovations, 9(2), 69-80.

Ramazan, Y., \& Bilal, I. (2018). Sharia Screening Methodology- New Sharia Compliant Approach. MPRA, Paper No. 90277, 167-189.

Sakti, M. R., Syahid, A., Tareq, M. A., \& Mahdzir, A. M. (2016). Shari'ah issues, challenges, and prospects for Islamic derivatives: A qualitative study. Qualitative Research in Financial Markets, 8(2), 168-190. 
https://doi.org/10.1108/QRFM-06-2015-0024

Sherif, M., \& Lusyana, D. (2017). Shariah-Compliant Investments and Stock Returns: Evidence from the Indonesian Stock Market. Journal of Islamic Accounting and Business Research, 8(2), 1-27. https://doi.org/10.1108/QRFM-06-2015-0024

Siddiqui, R. (2007). Shari'ah Compliance, Performance, and Conversion: The Case of the Dow Jones Islamic Market Index. Chicago Journal of International Law, 7(2), 495-519.

Syed, N. A. (2017). Building trust in Islamic finance products and services. Society and Business Review, 12(3), 356-372. https://doi.org/10.1108/QRFM-06-2015-0024

The MSCI Global Islamic Indices. (2013). Retrieved from http://www.msci.com/products/indices/thematic/faith-based/islamic/

Yesuf, A. J. (2017). Islamic Economics and Finance in Sudan: An Overview. IKAM Research Center for Islamic Economics, Report No.4, 1-57.

Appendix 1. Communalities for determination of sample adequacy

\begin{tabular}{|c|c|c|}
\hline & Initial & Extraction \\
\hline Most capital market participants know Sharia screening criteria & 1.000 & .443 \\
\hline Figh scholars accept screening criteria because they are Sharia based. & 1.000 & .289 \\
\hline The Mix of Halal and Haram activities necessitates application of screening criteria & 1.000 & .377 \\
\hline New challenges in capital markets necessitates developing screening criteria & 1.000 & .280 \\
\hline Screening criteria is capable of providing more information to the Muslim investor & 1.000 & .811 \\
\hline Applying the screening criteria locally benefits the listed companies & 1.000 & .680 \\
\hline Applying screening criteria locally is of no economic benefits to the listed companies & 1.000 & .000 \\
\hline Application of screening criteria locally has no economic benefits because the Sudanese capital markets is still infant. & 1.000 & .010 \\
\hline Granting Fatwas to deal in Haram activities will lead to its mix with Halal activities & 1.000 & .014 \\
\hline Sudanese investors believe that Haram activities do exist locally & 1.000 & .358 \\
\hline The application of screening criteria locally is regarded as a safe-belt for foreign investors. & 1.000 & .340 \\
\hline Applying screening criteria will not increase the bureaucracy of economic activities & 1.000 & .076 \\
\hline Application of screening criteria is regarded as complementary to the Sharia compliance circle. & 1.000 & .577 \\
\hline Associated screening criteria application costs are acceptable. & 1.000 & .361 \\
\hline Application of screening criteria locally attracts foreign Islamic investments. & 1.000 & .481 \\
\hline Local Sudanese experts are able to apply screening criteria. & 1.000 & .374 \\
\hline Application of screening criteria needs Fatwa from local related Sharia regulators. & 1.000 & .420 \\
\hline It is of most benefits to apply screening criteria gradually. & 1.000 & .339 \\
\hline Non-Islamic entities could be relieved from the application of screening criteria. & 1.000 & .053 \\
\hline It is of benefits to disseminate the culture of screening criteria. & 1.000 & .456 \\
\hline Fund managers and local brokers need to enhance their knowledge of screening criteria. & 1.000 & .267 \\
\hline There is a lack of local regulatory unit responsible of announcing assets Sharia compliance. & 1.000 & .006 \\
\hline Naming regulatory unit will help enhance effective capital market operations. & 1.000 & .216 \\
\hline $\begin{array}{l}\text { Certified accountants are able to formulate independent opinions about their customers' compliance with screening } \\
\text { criteria. }\end{array}$ & 1.000 & .621 \\
\hline Certified accountants are capable of assessing their customers' compliance with screening criteria. & 1.000 & .634 \\
\hline Certified accountants need to increase their knowledge and application of screening criteria & 1.000 & .075 \\
\hline Local investors depend on the financial reports of certified accountants when taking investment decisions. & 1.000 & .478 \\
\hline Khartoum Stock Exchange (KSE) uses the financial reports of certified accountants as assets' prices monitor. & 1.000 & .498 \\
\hline (KSE) has proper tools to make use of the financial reports of certified accountants as assets' prices monitor & 1.000 & .462 \\
\hline Auditor General office represents a fundamental pillar in passing regulations and Sharia criteria & 1.000 & .593 \\
\hline $\begin{array}{l}\text { Accounting and Auditing Org. Council lack the necessary tools to train licensed auditors on the application of screening } \\
\text { criteria }\end{array}$ & 1.000 & .405 \\
\hline Announcing customers' Sharia compliance by certified auditors is of benefits to the capital market. & 1.000 & .568 \\
\hline $\begin{array}{l}\text { Announcing customers' Sharia compliance by certified auditors compliments Sharia reports issued by other Sharia } \\
\text { authorities. }\end{array}$ & 1.000 & .609 \\
\hline
\end{tabular}

\section{Copyrights}

Copyright for this article is retained by the author(s), with first publication rights granted to the journal.

This is an open-access article distributed under the terms and conditions of the Creative Commons Attribution license (http://creativecommons.org/licenses/by/4.0/). 